\title{
Meta-analysis of long-term mobile phone use and the association with brain tumours
}

\author{
LENNART HARDELL $^{1}$, MICHAEL CARLBERG ${ }^{1}$, FREDRIK SÖDERQVIST ${ }^{1,2}$ and KJELL HANSSON MILD ${ }^{3}$ \\ ${ }^{1}$ Department of Oncology, University Hospital; ${ }^{2}$ Institute of Clinical Medicine, Örebro University, SE-701 85 Örebro; \\ ${ }^{3}$ Department of Radiation Physics, Umeå University, SE-901 87 Umeå, Sweden
}

Received January 18, 2008; Accepted March 4, 2008

\begin{abstract}
We evaluated long-term use of mobile phones and the risk for brain tumours in case-control studies published so far on this issue. We identified ten studies on glioma and meta-analysis yielded OR $=0.9,95 \% \mathrm{CI}=0.8-1.1$. Latency period of $\geq 10$-years gave $\mathrm{OR}=1.2,95 \% \mathrm{CI}=0.8-1.9$ based on six studies, for ipsilateral use (same side as tumour) $\mathrm{OR}=2.0$, 95\% CI $=1.2-3.4$ (four studies), but contralateral use did not increase the risk significantly, $\mathrm{OR}=1.1,95 \% \mathrm{CI}=0.6-2.0$. Meta-analysis of nine studies on acoustic neuroma gave $\mathrm{OR}=0.9,95 \% \mathrm{CI}=0.7-1.1$ increasing to $\mathrm{OR}=1.3,95 \%$ $\mathrm{CI}=0.6-2.8$ using $\geq 10$-years latency period (four studies). Ipsilateral use gave $\mathrm{OR}=2.4,95 \% \mathrm{CI}=1.1-5.3$ and contralateral $\mathrm{OR}=1.2,95 \% \mathrm{CI}=0.7-2.2$ in the $\geq 10$-years latency period group (three studies). Seven studies gave results for meningioma yielding overall $\mathrm{OR}=0.8,95 \% \mathrm{CI}=0.7-0.99$. Using $\geq 10$-years latency period $\mathrm{OR}=1.3,95 \% \mathrm{CI}=0.9-1.8$ was calculated (four studies) increasing to $\mathrm{OR}=1.7,95 \% \mathrm{CI}$ $=0.99-3.1$ for ipsilateral use and $\mathrm{OR}=1.0,95 \% \mathrm{CI}=0.3-3.1$ for contralateral use (two studies). We conclude that this meta-analysis gave a consistent pattern of an association between mobile phone use and ipsilateral glioma and acoustic neuroma using $\geq 10$-years latency period.
\end{abstract}

\section{Introduction}

Worldwide there has been a rapid development of wireless technology and along with that an increased use of wireless telephone communication during the last decade. Everyone is exposed to radiofrequency/microwave (RF) radiation emissions from wireless devices such as cellular phones and cordless phones, cellular antennas and towers, broadcast transmission towers, voice and data transmission for cell phones, pagers and personal digital assistants (PDAs) and other sources of RF radiation. This has raised concern of health risks, primarily an increased risk for brain tumours since the brain is the target organ for microwave exposure during mobile phone calls.

Correspondence to: Professor Lennart Hardell, Department of Oncology, University Hospital, SE-701 85 Örebro, Sweden

E-mail: lennart.hardell@orebroll.se

Key words: mobile phone, brain tumours, meta-analysis, latency period
Since Sweden was one of the first countries in the world to adopt this wireless technology a brief history is given in the following. First, analogue phones (NMT; Nordic Mobile Telephone System) were introduced on the market in the early 1980's using both 450 and 900 Megahertz (MHz) fields. NMT 450 was used in Sweden since 1981 but closed down in December 31, 2007, whereas NMT 900 operated during 1986-2000.

The digital system (GSM; Global System for Mobile Communication) using dual band, 900 and 1,800 MHz, started to operate in 1991 and now dominates the market. The third generation of mobile phones, $3 \mathrm{G}$ or UMTS (Universal Mobile Telecommunication System), using 1,900 MHz RF fields has been introduced worldwide since a few years, in Sweden in 2003.

Desktop cordless phones (DECT) started in 1988 using first analogue 800-900 MHz RF fields, but since early 1990's the digital 1,900 $\mathrm{MHz}$ system. In our studies on tumour risk associated with use of wireless phones we have also assessed use of DECT. However, most other research groups have not published such data or only in a scanty way, so exposure to $\mathrm{RF}$ from DECT is not further discussed here. Instead the reader is referred to our publications with the results as published previously (1-3).

The initial studies on brain tumour risk had too short latency periods to give a meaningful interpretation of long-term risk. However, during recent years studies have been published that enable evaluation of $\geq 10$-years latency period risk, although still mostly based on low numbers $(4,5)$. A $\geq 10$-years latency period seems to be a reasonable minimum period to indicate long-term carcinogenic risks from exposure to RF fields during use of cellular or cordless phones.

Long-term exposure to RF fields from mobile phones and brain tumour risk is of importance to evaluate not the least since the use of cellular phones is globally widespread with high prevalence among almost all age groups in the population.

\section{Materials and methods}

In addition to our constant gathering of new studies in this area we used the Pub Med database (www.ncbi.nlm.nih.gov) for search of all relevant studies. We used mobile/cellular/ cordless telephone and brain tumour/neoplasm/acoustic neuroma/meningioma/glioma as searching terms. If a study had several publications on certain aspects we used the latest publication giving the most relevant data. 
Table I. Odds ratios (ORs) and 95\% confidence intervals (CIs) from 10 case-control studies on glioma including meta-analysis of the studies. ${ }^{\text {a }}$

Study

Author, year of publication, country, ref. no.

No. of cases No. of controls OR $\quad 95 \%$ CI

Inskip et al 2001, USA (12)

Auvinen et al 2002, Finland (13)

Lönn et al 2005, Sweden (14)

$\begin{array}{cccc}201 & 358 & 1.0 & 0.7-1.4 \\ \text { Not given } & \text { Not given } & 1.5 & 1.0-2.4 \\ 214 & 399 & 0.8 & 0.6-1.0 \\ 47 & 90 & 1.1 & 0.6-2.0 \\ 59 & 155 & 0.6 & 0.4-0.9 \\ 508 & 898 & 0.9 & 0.8-1.1 \\ 138 & 283 & 1.0 & 0.7-1.3 \\ 346 & 900 & 1.4 & 1.1-1.7 \\ 65 & 900 & 1.4 & 0.9-2.3 \\ 281 & 900 & 1.4 & 1.1-1.8 \\ 867 & 1,853 & 0.8 & 0.7-0.9 \\ 59 & 54 & 1.2 & 0.7-2.1 \\ 161 & 227 & 0.6 & 0.4-0.9\end{array}$

Christensen et al 2005, low-grade glioma, Denmark (15)

Christensen et al 2005, high-grade glioma, Denmark (15)

Hepworth et al 2006, UK (16)

Schüz et al 2006, Germany (17)

Hardell et al 2006, Sweden (1), all glioma

Low-grade glioma

High-grade glioma

Lahkola et al 2006, Denmark, Norway, Finland, Sweden, UK (18)

Hours et al 2007, France (19)

Klaeboe et al 2007, Norway (20)

Not given ${ }^{\mathrm{b}}$

Not given ${ }^{\mathrm{b}}$

$0.9 \quad 0.8-1.1$

Meta-analysis

Not given

${ }^{\mathrm{a} N u m b e r s}$ of exposed cases and controls are given. ${ }^{\mathrm{b}}$ Total number could not be calculated since numbers were not presented in one publication (13).

Brain tumours include both malignant and benign types. Thus, it is worthwhile to give results for different types and in the following we discuss glioma, acoustic neuroma and meningioma, the major tumour types, separately. Compared with our previous publications $(4,5)$ we have now up-dated the number of included studies and made some further analysis. For details about the studies the reader is referred to our previous reviews and the original studies. We give overall results as well as $\geq 10$-years latency period results and, if presented, ipsilateral use of the cellular phones, i.e. same side of tumour and microwave exposure, and contralateral (opposite side) use. If the study did not have users with a $\geq 10$-year latency period only the overall results are presented.

Statistical methods. For statistical analysis Stata 8.2 was used (Stata/SE 8.2 for Windows; StataCorp., College Station TX). Random effects model was used for all meta-analysis, to allow for between-study statistical heterogeneity. The analyses were based on the adjusted ORs in the different studies. In our studies $(1,2)$ the unexposed group consisted of cases and controls with no reported use of either mobile or cordless phones. On the contrary almost all other studies did not assess use of cordless phones, and cases and controls with such use were included in the 'unexposed' group when mobile phone use was analyzed.

\section{Results}

We identified two publications from a cohort study of mobile phone users $(6,7)$ and 19 case-control studies on this topic (1,2,8-25; note refs. 8 and 9 are the same study). Two publications $(18,23)$ overlapped partly already published studies, but were included since also new results were presented in these publications. No mortality studies were included.

The Danish cohort study with two publications $(6,7)$ had several limitations, such as exclusion of the heaviest mobile phone users, no truly unexposed comparison group, skewed sex distribution and no data were given on laterality of phone use in relation to tumour localisation in the brain. This study was uninformative regarding long-term health effects from mobile phone use, as has been discussed elsewhere (4). Furthermore, this was a cohort study that gave standardised incidence rates and not odds ratios (OR) and 95\% confidence intervals $(\mathrm{CI})$ as in the case-control studies. For these reasons this cohort study was excluded from this review.

Two case-control studies were excluded since results were not presented separately for glioma, acoustic neuroma and meningioma (8-10). Our first study on this topic was the first one to indicate an association between use of mobile phones and ipsilateral brain tumours, although based on low numbers $(8,9)$. In one case-control study on acoustic neuroma overall results were not presented, only for some time periods without data for $\geq 10$-years latency period, and it was thus excluded from this review (11). The following presentation was based on results from 16 case-control studies.

Glioma. Ten case-control studies gave results for glioma risk associated with the use of mobile phones $(1,12-20)$. Seven of these studies (14-20) were part of the Interphone study on this issue, and one of these (18) overlapped partly three of other Interphone studies (14-16) but included also results for Finland (Table I). Later also results form Norway have been published separately (20). It should be noted that in one study the group of glioma cases was heterogenic including also ependymoma, i.e., a benign tumour, but probably few subjects 
Table II. Odds ratios (ORs) and 95\% confidence intervals (CIs) from 6 case-control studies on glioma including meta-analysis of the studies using $\geq 10$ years latency period. ${ }^{\text {a }}$

\begin{tabular}{|c|c|c|c|c|c|c|c|c|c|}
\hline \multirow[b]{2}{*}{$\begin{array}{l}\text { Study } \\
\text { Author, year of publication, country, } \\
\text { latency, refs. no. }\end{array}$} & \multicolumn{3}{|c|}{ Total } & \multicolumn{3}{|c|}{ Ipsilateral } & \multicolumn{3}{|c|}{ Contralateral } \\
\hline & $\begin{array}{l}\text { No. of } \\
\text { cases/ } \\
\text { controls }\end{array}$ & OR & $95 \% \mathrm{CI}$ & $\begin{array}{l}\text { No. of } \\
\text { cases/ } \\
\text { controls }\end{array}$ & OR & $95 \%$ CI & $\begin{array}{l}\text { No. of } \\
\text { cases/ } \\
\text { controls }\end{array}$ & OR & $95 \% \mathrm{CI}$ \\
\hline $\begin{array}{l}\text { Lönn } \text { et al } 2005, \text { Sweden, } \\
\geq 10 \text { years }(14)\end{array}$ & $25 / 38$ & 0.9 & $0.5-1.5$ & $15 / 18$ & 1.6 & $0.8-3.4$ & $11 / 25$ & 0.7 & $0.3-1.5$ \\
\hline $\begin{array}{l}\text { Christensen } \text { et al } 2005, \text { Denmark, } \\
\text { low-grade glioma, } \\
\geq 10 \text { years }(15)\end{array}$ & $6 / 9$ & 1.6 & $0.4-6.1$ & - & - & - & - & - & - \\
\hline $\begin{array}{l}\text { Christensen } \text { et al } 2005, \text { Denmark, } \\
\text { high-grade glioma, } \\
\geq 10 \text { years }(15)\end{array}$ & $8 / 22$ & 0.5 & $0.2-1.3$ & - & - & - & - & - & - \\
\hline $\begin{array}{l}\text { Hepworth et al } 2006, \mathrm{UK}, \\
>10 \text { years }(16)\end{array}$ & $66 / 112$ & 0.9 & $0.6-1.3$ & $\begin{array}{l}\text { Not } \\
\text { given }^{\mathrm{b}}\end{array}$ & 1.6 & $0.9-2.8$ & $\begin{array}{l}\text { Not } \\
\text { given }^{\mathrm{b}}\end{array}$ & 0.8 & $0.4-1.4$ \\
\hline $\begin{array}{l}\text { Schüz et al } 2006, \text { Germany, } \\
\geq 10 \text { years (17) }\end{array}$ & $12 / 11$ & 2.2 & $0.9-5.1$ & - & - & - & - & - & - \\
\hline $\begin{array}{l}\text { Hardell et al } 2006, \text { Sweden, } \\
>10 \text { years }(1), \text { all glioma }\end{array}$ & 78/99 & 2.7 & $1.8-3.9$ & $41 / 28$ & 4.4 & $2.5-7.6$ & $26 / 29$ & 2.8 & $1.5-5.1$ \\
\hline Low-grade glioma & $7 / 99$ & 1.5 & $0.6-3.8$ & $2 / 28$ & 1.2 & $0.3-5.8$ & $4 / 29$ & 2.1 & $0.6-7.6$ \\
\hline High-grade glioma & $71 / 99$ & 3.1 & $2.0-4.6$ & $39 / 28$ & 5.4 & $3.0-9.6$ & $22 / 29$ & 3.1 & $1.6-5.9$ \\
\hline $\begin{array}{l}\text { Lahkola et al 2006, Denmark, Norway, } \\
\text { Finland, Sweden, UK, } \geq 10 \text { years (18) }\end{array}$ & $143 / 220$ & 0.95 & $0.7-1.2$ & $77 / 117$ & 1.4 & $1.01-1.9$ & $67 / 121$ & 1.0 & $0.7-1.4$ \\
\hline Meta-analysis & $338 / 511$ & 1.2 & $0.8-1.9$ & $\begin{array}{l}\text { Not } \\
\text { given }^{\mathrm{b}}\end{array}$ & 2.0 & $1.2-3.4$ & $\begin{array}{l}\text { Not } \\
\text { given }^{\mathrm{b}}\end{array}$ & 1.1 & $0.6-2.0$ \\
\hline
\end{tabular}

${ }^{a}$ Numbers of exposed cases and controls are given. ${ }^{b}$ Total number could not be calculated since numbers were not presented in one publication (16).

(13). The risk was significantly decreased in the Danish part (15) for high-grade glioma with $\mathrm{OR}=0.6,95 \% \mathrm{CI}=0.4-0.9$, for all glioma in the study in Norway (20) with OR $=0.6$, 95\% CI $=0.4-0.9$, and the Finnish publication (18) with $\mathrm{OR}=0.8,95 \% \mathrm{CI}=0.7-0.9$. In the Swedish part of Interphone studies decreased OR of borderline significance was presented (14). In a register based case-control study from Finland (13), that was not part of the Interphone study, an increased OR $=1.5$ of borderline significance was reported (95\% CI $=1.0-2.4)$. In our Swedish study (1), independent from Interphone, OR $=1.4,95 \% \mathrm{CI}=1.1-1.7$ was reported for all glioma. Metaanalysis of the 10 case-control studies yielded OR $=0.9,95 \%$ $\mathrm{CI}=0.8-1.1$.

In Table II results are presented for the six studies (1,14-18) that gave results for a latency period of at least 10 years. Most of the results in the various studies were based on low numbers. Meta-analysis gave $\mathrm{OR}=1.2,95 \% \mathrm{CI}=0.8-1.9$. In four casecontrol studies results for ipsilateral use of a mobile phone were presented $(1,14,16,18)$. All showed increased OR and meta-analysis yielded $\mathrm{OR}=2.0,95 \% \mathrm{CI}=1.2-3.4$. However, contralateral use did not increase the risk significantly, OR = $1.1,95 \% \mathrm{CI}=0.6-2.0$.
Acoustic neuroma. Regarding acoustic neuroma nine casecontrol studies have been published, Table III $(2,12,19-25)$. Seven of these were part of the Interphone studies (19-25). One of these (23) overlapped partly two other Interphone studies $(21,22)$ and one published later $(20)$. One of the largest studies came from Sweden and was not part of the Interphone studies (2). It gave significantly increased OR $=1.7,95 \% \mathrm{CI}$ $=1.2-2.3$. Six of the seven Interphone studies reported somewhat decreased ORs, although not significantly so. Meta-analysis gave $\mathrm{OR}=0.9,95 \% \mathrm{CI}=0.7-1.1$.

Results for a latency period of 10 years or more were reported in four $(2,21-23)$ of these nine studies (Table IV). Again, using this latency period most of the results were based on low numbers. In total, meta-analysis gave $\mathrm{OR}=1.3$, $95 \% \mathrm{CI}=0.6-2.8$, whereas for ipsilateral use of the mobile phone OR increased to $2.4,95 \% \mathrm{CI}=1.1-5.3$, based on three studies. Contralateral use yielded $\mathrm{OR}=1.2,95 \% \mathrm{CI}=0.7-2.2$.

Meningioma. For meningioma results have been published from seven case-control studies, Table V $(2,12,14,15,17,19,20)$. Of these, five $(14,15,17,19,20)$ were part of the Interphone study and all gave decreased OR for meningioma, significantly 
Table III. Odds ratios (ORs) and 95\% confidence intervals (CIs) from 9 case-control studies on acoustic neuroma including meta-analysis of the studies. ${ }^{a}$

\begin{tabular}{lcccr}
\hline $\begin{array}{l}\text { Study } \\
\text { Author, year of publication, country, ref. no. }\end{array}$ & No. of cases & No. of controls & OR & $95 \%$ CI \\
\hline Inskip et al 2001, USA (12) & 40 & 358 & 0.8 & $0.5-1.4$ \\
Lönn et al 2004, Sweden (21) & 89 & 356 & 1.0 & $0.6-1.5$ \\
Christensen et al 2004, Denmark (22) & 45 & 97 & 0.9 & $0.5-1.6$ \\
Schoemaker et al 2005, Denmark, Finland, Sweden, & 360 & 1,934 & 0.9 & $0.7-1.1$ \\
Norway, Scotland, UK (23) & & & & \\
Hardell et al 2006, Sweden (2) & 130 & 900 & 1.7 & $1.2-2.3$ \\
Takebayashi et al 2006, Japan (24) & 51 & 192 & 0.7 & $0.4-1.2$ \\
Klaeboe et al 2007, Norway (20) & 22 & 227 & 0.5 & $0.2-1.0$ \\
Schlehofer et al 2007, Germany (25) & 29 & 74 & 0.7 & $0.4-1.2$ \\
Hours et al 2007, France (19) & 58 & 123 & 0.9 & $0.5-1.6$ \\
Meta-analysis & 824 & 4,261 & 0.9 & $0.7-1.1$ \\
\hline
\end{tabular}

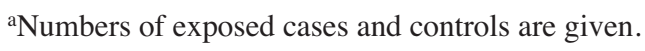

Table IV. Odds ratios (ORs) and 95\% confidence intervals (CIs) from 4 case-control studies on acoustic neuroma including meta-analysis of the studies using $\geq 10$ years latency period. ${ }^{a}$

\begin{tabular}{|c|c|c|c|c|c|c|c|c|c|}
\hline \multirow[b]{2}{*}{$\begin{array}{l}\text { Study } \\
\text { Author, year of publication, country, } \\
\text { latency, refs. no. }\end{array}$} & \multicolumn{3}{|c|}{ Total } & \multicolumn{3}{|c|}{ Ipsilateral } & \multicolumn{3}{|c|}{ Contralateral } \\
\hline & $\begin{array}{l}\text { No. of } \\
\text { cases/ } \\
\text { controls }\end{array}$ & OR & $95 \% \mathrm{CI}$ & $\begin{array}{l}\text { No. of } \\
\text { cases/ } \\
\text { controls }\end{array}$ & OR & $95 \% \mathrm{CI}$ & $\begin{array}{l}\text { No. of } \\
\text { cases/ } \\
\text { controls }\end{array}$ & OR & $95 \% \mathrm{CI}$ \\
\hline $\begin{array}{l}\text { Lönn et al } 2004, \text { Sweden, } \\
\geq 10 \text { years }(21)\end{array}$ & $14 / 29$ & 1.8 & $0.8-4.3$ & $12 / 15$ & 3.9 & $1.6-9.5$ & $4 / 17$ & 0.8 & $0.2-2.9$ \\
\hline $\begin{array}{l}\text { Christensen } \text { et al } 2004, \text { Denmark, } \\
\geq 10 \text { years }(22)\end{array}$ & $2 / 15$ & 0.2 & $0.04-1.1$ & - & - & - & - & - & - \\
\hline $\begin{array}{l}\text { Schoemaker et al } 2005 \text {, Denmark, Finland, } \\
\text { Sweden, Norway, Scotland, UK, } \\
\geq 10 \text { years ( } 23 \text { ) }\end{array}$ & $47 / 212$ & 1.0 & $0.7-1.5$ & $31 / 124$ & 1.3 & $0.8-2.0$ & $20 / 105$ & 1.0 & $0.6-1.7$ \\
\hline Hardell et al 2006, Sweden, >10 years (2) & $20 / 99$ & 2.9 & $1.6-5.5$ & $10 / 28$ & 3.5 & $1.5-7.8$ & $6 / 29$ & 2.4 & $0.9-6.3$ \\
\hline Meta-analysis & $83 / 355$ & 1.3 & $0.6-2.8$ & $53 / 167$ & 2.4 & $1.1-5.3$ & $30 / 151$ & 1.2 & $0.7-2.2$ \\
\hline
\end{tabular}

${ }^{a}$ Numbers of exposed cases and controls are given.

so in the Swedish part with $\mathrm{OR}=0.7,95 \% \mathrm{CI}=0.5-0.9$ (14). The largest study was a Swedish investigation independent from Interphone based on 347 exposed cases. It gave OR $=1.1$, $95 \% \mathrm{CI}=0.9-1.3$. Meta-analysis gave significantly decreased risk with $\mathrm{OR}=0.8,95 \% \mathrm{CI}=0.7-0.99$.

Four case-control studies remained for the analysis of a 10 -years latency period, Table VI $(2,14,15,17)$. In total no study showed significantly increased OR and meta-analysis gave $\mathrm{OR}=1.3,95 \% \mathrm{CI}=0.9-1.8$. The analysis of ipsilateral microwave exposure was based on two studies and the metaanalysis gave $\mathrm{OR}=1.7,95 \% \mathrm{CI}=0.99-3.1$. Regarding contralateral exposure no increased risk was found, $\mathrm{OR}=$ $1.0,95 \% \mathrm{CI}=0.3-3.1$.

\section{Discussion}

Different biological effects have been reported from exposure to radiofrequency/microwave fields, for an overview see two recent reports $(5,26)$. Of special concern is the risk for brain tumours due to the high near field exposure to the brain during mobile phone calls compared with other sources of RF fields. In total 19 case-control studies have been performed 
Table V. Odds ratios (ORs) and 95\% confidence intervals (CIs) from 7 case-control studies on meningioma including metaanalysis of the studies. ${ }^{\mathrm{a}}$

\begin{tabular}{lcccc}
\hline $\begin{array}{l}\text { Study } \\
\text { Author, year of publication, country, ref. no. }\end{array}$ & No. of cases & No. of controls & OR & $95 \%$ CI \\
\hline Inskip et al 2001 (USA) (12) & 67 & 358 & 0.8 & $0.5-1.2$ \\
Lönn et al 2005 (Sweden) (14) & 118 & 399 & 0.7 & $0.5-0.9$ \\
Christensen et al 2005 (Denmark) (15) & 67 & 133 & 0.8 & $0.5-1.3$ \\
Schüz et al 2006 (Germany) (17) & 104 & 234 & 0.8 & $0.6-1.1$ \\
Hardell et al 2006 (Sweden) (2) & 347 & 900 & 1.1 & $0.9-1.3$ \\
Klaeboe et al 2007 (Norway) (20) & 96 & 227 & 0.8 & $0.5-1.1$ \\
Hours et al 2007 (France) (19) & 71 & 80 & 0.7 & $0.4-1.3$ \\
Meta-analysis & 870 & 2,331 & 0.8 & $0.7-0.99$ \\
\hline
\end{tabular}

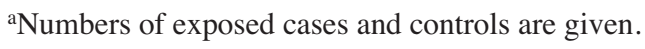

Table VI. Odds ratios (ORs) and 95\% confidence intervals (CIs) from 4 case-control studies on meningioma including metaanalysis of the studies using $\geq 10$ years latency period. ${ }^{a}$

\begin{tabular}{|c|c|c|c|c|c|c|c|c|c|}
\hline \multirow[b]{2}{*}{$\begin{array}{l}\text { Study } \\
\text { Author, year of publication, country, } \\
\text { latency, refs. no. }\end{array}$} & \multicolumn{3}{|c|}{ Total } & \multicolumn{3}{|c|}{ Ipsilateral } & \multicolumn{3}{|c|}{ Contralateral } \\
\hline & $\begin{array}{l}\text { No. of } \\
\text { cases/ } \\
\text { controls }\end{array}$ & OR & $95 \% \mathrm{CI}$ & $\begin{array}{l}\text { No. of } \\
\text { cases/ } \\
\text { controls }\end{array}$ & OR & $95 \% \mathrm{CI}$ & $\begin{array}{l}\text { No. of } \\
\text { cases/ } \\
\text { controls }\end{array}$ & OR & $95 \% \mathrm{CI}$ \\
\hline Lönn et al 2005, Sweden, $\geq 10$ years (14) & $12 / 36$ & 0.9 & $0.4-1.9$ & $5 / 18$ & 1.3 & $0.5-3.9$ & $3 / 23$ & 0.5 & $0.1-1.7$ \\
\hline $\begin{array}{l}\text { Christensen et al } 2005 \text {, Denmark, } \\
\geq 10 \text { years (15) }\end{array}$ & $6 / 8$ & 1.0 & $0.3-3.2$ & - & - & - & - & - & - \\
\hline Schüz et al 2006, Germany, $\geq 10$ years (17) & $5 / 9$ & 1.1 & $0.4-3.4$ & - & - & - & - & - & - \\
\hline Hardell et al 2006, Sweden, $\geq 10$ years (2) & $38 / 99$ & 1.5 & $0.98-2.4$ & $15 / 28$ & 2.0 & $0.98-3.9$ & $12 / 29$ & 1.6 & $0.7-3.3$ \\
\hline Meta-analysis & $61 / 152$ & 1.3 & $0.9-1.8$ & $20 / 46$ & 1.7 & $0.99-3.1$ & $15 / 52$ & 1.0 & $0.3-3.1$ \\
\hline
\end{tabular}

${ }^{a}$ Numbers of exposed cases and controls are given.

on that topic, but since few subjects have used the mobile phone for at least 10 years conclusions on long-term effects have been hampered. By now a number of studies exist with such data, so presentation of the results in the various studies is meaningful as well as meta-analysis of the data.

As to carcinogenesis usually latency period of at least 10 years is needed for more firm conclusions. For several carcinogens such as smoking and asbestos exposure and the risk for lung cancer, dioxins and certain cancer types even longer latency periods may be required $(27,28)$. Thus, it is premature to draw conclusions on the association between mobile phones and brain tumours based on short latency period, as has been the situation in some commentaries (29).

This review included 19 case-control studies. Two publications from a Danish cohort study on mobile phone users $(6,7)$ were excluded due to limitations in the study design, as discussed above. Our first study on this topic was excluded, since analysis was not performed for different histology types $(8,9)$. This was one of the first studies in this area and the first to indicate an association between mobile phone use and ipsilateral brain tumours. Two studies from USA were excluded for the same reason as our first one or because overall data were not presented $(10,11)$. However, in that study mobile phone use during 3-6 years, that was the longest observation time, gave $\mathrm{OR}=1.7,95 \% \mathrm{CI}=0.5-5.1$ based on 11 cases and 6 controls (11).

It should be noted that several of the overall ORs in the Interphone studies were $<1.0$, some even significantly so. As an example, in the Danish Interphone study on glioma (15) all 17 ORs for high-grade glioma were $<1.0$, four significantly decreased. In the Swedish Interphone study on glioma 46 ORs were presented with overall results (14). Of these ORs 45 were $<1.0$, six even signficantly so. On the contrary, regarding glioma using a latency period of $\geq 10$ years increased ORs for ipsilateral exposure were found in all Interphone studies that present such data, see Table II. The overall decreased risks would thus bias the 10-years latency period calculations towards unity. These results in the Interphone 
studies give concern about the methods used, such as assessment and interpretation of exposure and statistical analysis.

For biological reasons it is not believed that microwave exposure from mobile phones do prevent brain tumours, as indicated in some results in the Interphone studies. Thus, the design and performance of these studies, using the same core protocol, seem to be biased in certain respects. This has been discussed by others and us elsewhere $(4,5,30,31)$. In a Danish Interphone study it was concluded that the cognitive function in brain tumour cases was affected leading to e.g. deficient memory (15). Patients scored significantly lower than controls with problems to recall words (aphasia), writing and drawing due to paralysis.

Also the interviewing of cases in such short time after diagnosis in the Interphone studies, even bedside (e.g. 17), might have biased assessment of exposure due to a stressful situation for the patient with memory and other defects of the cognitive functions. It should further be noted that some of the Interphone studies had very low response rates with the possibility of selection bias. In the publication on mobile phone use and risk of glioma in five North European countries $37-81 \%$ (total $60 \%$ ) of the cases and $42-69 \%$ (total $50 \%$ ) of the controls participated (18). This is to be compared with the response rates in our studies $(1,2)$. Of cases with malignant brain tumours $905(90 \%)$ answered the questionnaire. The corresponding results were for cases with benign brain tumours $1,254(88 \%)$ and controls 2,162 (89\%).

In addition to selection bias of cases and controls in the Interphone studies, recall bias due to e.g. cognitive defects in the patients might have been introduced. Computer guided face-to-face interviews of cases at the hospitals shortly after operation may have been a contributing factor. We used postal questionnaires both for cases and controls. The cases could answer the questionnaire some time after the operation, usually about two months later. If necessary, the answers were supplemented over the phone. All assessment of exposure and coding of data in our studies were blinded as to case or control status. On the contrary, face-to-face interviews of both cases and controls in the Interphone studies might have introduced observational bias since it was known if it was a patient or a referent that was interviewed.

Some articles have discussed methodological issues in the Interphone studies $(30,31)$. The actual use of mobile phones was underestimated in light users and overestimated in heavy users. Random recall bias could lead to large underestimation in the risk of brain tumours associated with mobile phone use. It was further suggested that selection bias in the Interphone study resulted in under selection of unexposed controls with decreasing risk at low to moderate exposure levels.

Furthermore, it should be added that in our studies we also assessed use of cordless phones $(1,2)$. The unexposed group consisted of cases and controls with no use of mobile or cordless phones. In contrast, e.g. the Interphone studies did not assess use of cordless phones or did not report any details $(14,17)$. Such use seems to have been included in the unexposed group in the statistical analysis of an association between mobile phone use and brain tumours. We found increased OR for glioma and acoustic neuroma associated with use of both mobile and cordless phones, whereas overall
OR was not significantly increased for meningioma $(1,2)$. It has been shown that the GSM phones have a median power in the same order of magnitude as cordless phones (32). Moreover, cordless phones are usually used for longer calls than mobile phones $(1,2)$. Including subjects using cordless phones in the 'unexposed' group in studies on this issue, as for example in the Interphone investigations, would thus underestimate the risk.

We report here results from ten case-control studies on glioma. No association was found with mobile phone use in the overall meta-analysis. However, using a $\geq 10$-years latency period showed increased OR in the four studies with data on ipsilateral use of the mobile phone, significantly so in the meta-analysis. Contralateral use yielded OR close to unity. These findings are most likely of biological relevance taking into account both a reasonable latency period and tumour localisation in relation to microwave exposure and should therefore be considered in relation to carcinogenesis $(33,34)$.

Since one publication on glioma (18) partly overlapped three other Interphone studies (14-16) we excluded them in one analysis. Later also results from Norway have been published but without any 10-years latency period data (20). Using $\geq 10$-years latency period yielded $\mathrm{OR}=1.7,95 \% \mathrm{CI}=$ $0.8-3.9$, ipsilateral exposure $\mathrm{OR}=2.4,95 \% \mathrm{CI}=0.8-7.4$ and contralateral exposure $\mathrm{OR}=1.6,95 \% \mathrm{CI}=0.6-4.4$.

Also regarding acoustic neuroma ipsilateral exposure to microwaves yielded increased OR in the three studies with such data, significantly so in the meta-analysis. Contralateral exposure did not give significantly increased OR. These findings are similar as for glioma. Since one of the Interphone publications $(23)$ partly overlapped two other $(21,22)$ with 10-years latency data we excluded these two studies in one analysis. Using $\geq 10$-years latency period yielded $\mathrm{OR}=1.7,95 \% \mathrm{CI}=0.6-4.7$, ipsilateral exposure $\mathrm{OR}=2.0$, $95 \% \mathrm{CI}=0.8-5.3$ and contralateral exposure $\mathrm{OR}=1.4$, $95 \% \mathrm{CI}=0.6-3.2$.

Results on meningioma for $\geq 10$ years latency period were presented in four studies and ipsilateral exposure in two investigations. Thus, these results were based on lower numbers than for glioma or acoustic neuroma. No significant association was found although ipsilateral exposure gave OR $=1.7$ with $95 \%$ CI $0.99-3.1$.

It might be discussed if the results would be changed if our studies $(1,2)$ were excluded from the meta-analysis. Regarding glioma this yielded for $\geq 10$-years latency period overall $\mathrm{OR}=1.0,95 \% \mathrm{CI}=0.8-1.2$, ipsilateral exposure $\mathrm{OR}=1.5$, $95 \% \mathrm{CI}=1.1-1.9$ and contralateral exposure $\mathrm{OR}=0.9,95 \%$ $\mathrm{CI}=0.7-1.2$. For acoustic neuroma the corresponding results gave overall $\mathrm{OR}=0.9,95 \% \mathrm{CI}=0.4-2.0$, ipsilateral exposure $\mathrm{OR}=2.1,95 \% \mathrm{CI}=0.7-6.1$ and contralateral exposure $\mathrm{OR}=$ $1.0,95 \% \mathrm{CI}=0.6-1.6$. Regarding meningioma overall $\mathrm{OR}$ was $1.0,95 \% \mathrm{CI}=0.6-1.6$. Only one study (14) remained for calculations of ipsilateral and contralateral exposure (Table VI).

As shown above an association was still found between mobile phone use and ipsilateral glioma and acoustic neuroma, significantly so for glioma, even if our studies $(1,2)$ were excluded. Another meta-analysis that did not include our studies found a significant association between mobile phone use and all brain tumours using $\geq 10$ years latency 
period with $\mathrm{OR}=1.25,95 \% \mathrm{CI}=1.01-1.54$ (35). One more meta-analysis was performed on mobile phone use yielding for contralateral brain tumours $\mathrm{OR}=1.0,95 \% \mathrm{CI}=0.8-1.4$ and for ipsilateral brain tumours $\mathrm{OR}=1.3,95 \% \mathrm{CI}=0.99-1.9$. No analysis was performed for $\geq 10$ year latency time (36).

In conclusion this meta-analysis gave a consistent pattern of an association between mobile phone use and ipsilateral glioma and acoustic neuroma using $\geq 10$-years latency period. No association was found for contralateral tumours. These results are most likely of biological relevance and further strengthen the hypothesis of a carcinogenic effect from microwave emissions from mobile phones.

\section{Acknowledgements}

This study was supported by a grant from Cancer- och Allergifonden.

\section{References}

1. Hardell L, Hansson Mild K and Carlberg M: Pooled analysis of two case-control studies on use of cellular and cordless telephones and the risk for malignant brain tumours diagnosed in 1997-2003. Int Arch Occup Environ Health 79: 630-639, 2006.

2. Hardell L, Carlberg M and Hansson Mild K: Pooled analysis of two case-control studies on the use of cellular and cordless telephones and the risk of benign tumours diagnosed during 1997-2003. Int J Oncol 28: 509-518, 2006.

3. Hardell L and Hansson Mild K: Cellular telephones and the risk for brain tumours. World J Surg Oncol 4: 74, 2006.

4. Hardell L, Carlberg M, Söderqvist F, Hansson Mild K and Morgan LL: Long-term use of cellular phones and brain tumours - increased risk associated with use for $\geq 10$ years. Occup Env Med 64: 626-632, 2007. DOI 10.1136/oem.2006.029751.

5. BioInitiative Report: A Rationale for a Biologically-based Public Exposure Standard for Electromagnetic Fields (ELF and RF). http://www .bioinitiative.org/ (assessed January 7, 2008).

6. Johansen C, Boice JD Jr, McLaughlin JK and Olsen JH: Cellular telephones and cancer - a nationwide cohort study in Denmark. J Natl Cancer Inst 93: 203-207, 2001.

7. Schüz J, Jacobsen R, Olsen JH, Boice JD Jr, McLaughlin JK and Johansen C: Cellular telephone use and cancer risks: update of a nationwide Danish cohort. J Natl Cancer Inst 98: 1707-1713, 2006.

8. Hardell L, Näsman $\AA$, Påhlson A, Hallquist A and Hansson Mild K: Use of cellular telephones and the risk for brain tumours: a case-control study. Int J Oncol 15: 113-116, 1999.

9. Hardell L, Hansson Mild K, Påhlson A and Hallquist A: Ionizing radiation, cellular telephones and the risk for brain tumours. Eur J Cancer Prev 10: 523-529, 2001.

10. Muscat JE, Malkin MG, Thompson S, et al: Handheld cellular telephone use and risk of brain cancer. JAMA 284: 3001-3007, 2000.

11. Muscat JE, Malkin MG, Shore RE, et al: Handheld cellular telephones and risk of acoustic neuroma. Neurology 58: 1304-1306, 2002.

12. Inskip PD, Tarone RE, Hatch EE, et al: Cellular-telephone use and brain tumors. N Engl J Med 344: 79-86, 2001.

13. Auvinen A, Hietanen M, Luukonen R and Koskela RS: Brain tumors and salivary gland cancers among cellular telephone users. Epidemiology 13: 356-359, 2002.

14. Lönn S, Ahlbom A, Hall P and Feychting M: Swedish Interphone Study Group. Long-term mobile phone use and brain tumor risk. Am J Epidemiol 161: 526-535, 2005.
15. Christensen HC, Schüz J, Kosteljanetz M, et al: Cellular telephones and risk for brain tumors: a population-based, incident case-control study. Neurology 64: 1189-1195, 2005.

16. Hepworth SJ, Schoemaker MJ, Muir KR, Swerdlow AJ, van Tongeren MJ and McKinney PA: Mobile phone use and risk of glioma in adults: case-control study. BMJ 332: 883-887, 2006.

17. Schüz J, Böhler E, Berg G, et al: Cellular phones, cordless phones, and the risks of glioma and meningioma (Interphone Study Group, Germany). Am J Epidemiol 163: 512-520, 2006.

18. Lahkola A, Auvinen A, Raitanen J, et al: Mobile phone use and risk of glioma in 5 North European countries. Int J Cancer 120: 1769-1775, 2007.

19. Hours M, Bernard M, Montestrucq L, et al: Cell phones and risk of brain and acoustic nerve tumours: the French INTERPHONE case-control study. Revue d'_pidèmiologie et de Santé Publique 55: 321-332, 2007.

20. Klaeboe L, Blaasaas KG and Tynes T: Use of mobile phones in Norway and risk of intracranial tumours. Eur J Cancer Prev 16: 158-164, 2007.

21. Lönn S, Ahlbom A, Hall P and Feychting M: Mobile phone use and the risk of acoustic neuroma. Epidemiology 15: 653-659, 2004.

22. Christensen HC, Schüz J, Kosteljanetz M, Poulsen HS, Thomsen $\mathrm{J}$ and Johansen $\mathrm{C}$ : Cellular telephone use and risk of acoustic neuroma. Am J Epidemiol 159: 277-283, 2004.

23. Schoemaker MJ, Swerdlow AJ, Ahlbom A, et al: Mobile phone use and risk of acoustic neuroma: results of the Interphone casecontrol study in five North European countries. Br J Cancer 93: 842-848, 2005 .

24. Takebayashi T, Akiba S, Kikuchi Y, et al: Mobile phone use and acoustic neuroma risk in Japan. Occup Environ Med 63: 802-807, 2006.

25. Schlehofer B, Schlaefer K, Blettner M, et al: Environmental risk factors for sporadic acoustic neuroma (Interphone Study Group, Germany). Eur J Cancer 43: 1741-1747, 2007.

26. Hardell L and Sage C: Biological effects from electromagnetic field exposure and public exposure standards. Biomed Pharmacother 62: 104-109, 2008.

27. IARC Monographs on the Evaluation of Carcinogenic Risks to Humans. Polychlorinated Dibenzo-Para-Dioxins and Polychlorinated Dibenzofurans. Vol. 69. IARC, Lyon, 1997.

28. IARC Monographs on the Evaluation of Carcinogenic Risk of Chemicals to Man. Asbestos. Vol. 14, IARC, Lyon, 1977.

29. Trichopoulos D and Adami HO: Cellular telephones and brain tumors. N Engl J Med 344: 133-134, 2001.

30. Vrijheid M, Cardis E, Armstrong BK, et al: Validation of short term recall of mobile phone use for the Interphone study. Occup Environ Med 63: 237-243, 2006.

31. Vrijheid M, Deltour I, Krewski D, Sanchez M and Cardis E: The effects of recall errors and selection bias in epidemiologic studies of mobile phone use and cancer risk. J Expos Sci Environ Epidemiol 16: 371-384, 2006.

32. Hansson Mild K, Hardell L, Kundi M and Mattsson MO: Mobile phones and cancer: is there really no evidence of an association (Review)? Int J Mol Med 12: 67-72, 2003.

33. Belpomme D, Irigaray P, Sasco AJ, et al: The growing incidence of cancer: role of lifestyle and screening detection (Review). Int J Oncol 30: 1037-1049, 2007.

34. Belpomme D, Irigaray $\mathrm{P}$, Hardell L, et al: The multitude and diversity of environmental carcinogens. Env Res 105: 414-429, 2007.

35. Kan P, Simonsen SE, Lyon JL and Kestle JR: Cellular phone use and brain tumor: a meta-analysis. J Neurooncol 86: 71-78, 2008.

36. Lahkola A, Tokola K and Auvinen A: Meta-analysis of mobile phone use and intracranial tumors. Scand J Work Environ Health 32: 171-177, 2006. 